\title{
Scattered Neuroendocrine Cells by Immunohistochemistry Present
}

National Cancer Institute

\section{Source}

National Cancer Institute. Scattered Neuroendocrine Cells by Immunohistochemistry

Present. NCI Thesaurus. Code C158657.

A morphologic finding indicating the presence of scattered neuroendocrine cells by immunohistochemistry in a cellular infiltrate. 